\title{
ALVORADA LÁ NO MORRO, QUE BELEZA! HERMÍNIO, A PAISAGEM E AS CORES DO SAMBA
}

RESUMO: Há, nas letras de alguns sambas que falam sobre as paisagens dos morros cariocas, riqueza de descrição, e uso de fala lírica, que acabam por representar pinturas na imaginação dos apreciadores. Neste texto, foram reunidas algumas dessas canções, em uma disposição adequada para a satisfação estética do observador, como se ele estivesse passando por quadros em exposição na mostra de arte focando paisagens típicas do morro carioca, priorizando-se as "pinturas" elaboradas pela escrita do poeta e letrista Hermínio Bello de Carvalho.

PALAVRAS-CHAVE: Samba; morro; paisagens.

ABSTRACT: There's, in the lyrics of some sambas talking about the landscapes of slums on the hills in Rio, a wealth of description and a speech of great lyricism, which end up creating real paintings in the imagination of connoisseurs. In this paper, we paintings in the imagination of connoisseurs. In this paper, we
have been brought together some of these songs in a proper disposition for aesthetic satisfaction and observer's accurate assimilation, as if he were going through paintings displayed in art gallery, focusing on typical landscapes of Rio's slum hills, giving priority to the "paintings" drawn up by lyrics of the poet and lyricist Hermínio Bello de Carvalho.

KEYWORDS: Samba; slum hills; landscapes. 
1. CAETANO. 54 anos de música popular brasileira, p. 48

2. FAUSTINO. Que é poesia?, p. 70.
Deus, dando a paisagem, Metade do céu já é meu

Deus, dando a paisagem

O resto e só ter coragen

Hermínio Bello de Carvalho, Zé Keti

Quando se fala em pinturas desvelando o universo do samba, pensa-se logo na faceta pictórica da arte do mestre Heitor dos Prazeres. Com seus quadros fartamente coloridos, mostra a vida peculiar desse mundo, construída nas rodas de canção e dança, nos terreiros ou nos botequins. Existem, porém, no mundo do samba, canções que, no imaginário dos ouvintes, constituem perfeitos quadros, matizados por cores brilhantes, retratando paisagens daqueles lugares que, a despeito de oprimidos, reprimidos, contestados e perseguidos, se metamorfoseiam, na poética do cancioneiro popular, em utópicos reinos encantados, esbanjando traços e cores.

Aqui, não se pretende enfrentar a discussão, nunca pacificada, de se comparar letra de música a poema, ou separar uma do outro, ou a de apontar poesia nas artes visuais. Como diz Pedro Caetano ${ }^{1}$, referindo-se à primeira das discussões, não se deve confundir as duas coisas já que "embora todo poeta possa ser letrista, nem todo letrista consegue ser poeta”. Quanto à segunda discussão, melhor se ater, por ora, ao esclarecimento de Mário Faustino ${ }^{2}$ para quem, pelo entendimento canônico atual, poesia "se trata antes de tudo, de uma maneira de ser da literatura, ou seja, da arte da palavra, da arte de exprimir percepções através de palavras". Naturalmente, escritas. De difícil comparação também os fazeres artísticos da canção com a arte pictórica. Gêneros absolutamente distintos que, ainda que por vezes dialoguem, nunca se confundem, no que pesem experiências de "pinturas literárias", "livros de artista" e "poesia visual”. O que não impede que se busque, como aqui se pretende fazer, para além dos horizontes da imaginação, a visualização de "quadros" mentais instigados pelo fazer poético das letras de canções, evocando paisagens dignas da acuidade perceptiva do ouvinte, receptor-expectador. A comparação entre linguagem (incluindo a letra de canção) e pintura só é possível, no dizer de Merleau-Ponty, invocando Malraux, na concepção de expressão criadora ${ }^{3}$, enquanto outros elementos homólogos ou de contato interartes vão ser trazidos por interdiscursividade, intertextualidade ou dialogia.

Sob a visão da Literatura comparada é que se pode perceber a proximidade relacional entre imagem e texto, o que, no dizer Karl Erik Schøllhammer, "abre um campo fértil para o estudo da Literatura numa cidade cada vez mais absorvidas pelas dinâmicas da cultura da imagem”, além de permitir "formar um melhor entendimento acerca do funcionamento das imagens, compreendidas como mediações significativas da realidade"
3. MEARLEAU-PONTY. A prosa do mundo, p. 95-96; 107-108.
EM TESE

BELO HORIZONTE
N. 3

SET.-DEZ. 2015
4. SCHØLLHAMMER, Karl Erik. Além do visivel: o olhar da Literatura, p. 11. 
5. A notícia pode ser vista, na rede mundial de computadores, na publicação " $\mathrm{GQ}$ " on line de 21 fev. 2015, no endereço <http://gq.globo.com/Cultura/ noticia/2015/07/musicos-fazem instalinspiradas.
Pela evocação da imagem mental na canção e sua aproximação com a maneira de fruir esteticamente a apreciação de pinturas, é que se encontram as relações comparativas invocadas neste texto. A profundidade distintiva de gêneros não impede a relação homológica. Não raro, o relacionamento prático música-pintura é evidenciado em exposições, em livros ou em outros meios de comunicação e, apenas como um singelo exemplo, cita-se aqui a mostra Soundscapes promovida por The National Gallery de Londres, entre 8 de julho e 6 de setembro de 2015, quando Jamie xx, da banda The $\mathrm{xx}$, Gabriel Yared, vencedor Oscar pela música de O Paciente Inglês, e Susan Philipsz, vencedora do Prêmio Turner, compartilharam e exploraram, junto a outros renomados artistas da música, as sensações percebidas em quadros de grandes pintores, também expostos ${ }^{5}$.

Heitor dos Prazeres, que também e originariamente era músico e sambista, pintou quadros que dialogam francamente com o mundo das canções do samba. Por outro lado ainda que não haja um diálogo direto, na composição de sambas, algumas letras invocam imagens marcantes, muitas vezes usando linguagem que lembra a descrição de pinturas e que, se pintadas, atrairiam significativo interesse. E, assim, constroem cenários idealizados, transfigurando a cena do real na paisagem ideal. Ataulfo Alves, o sambista da "pequenina" Miraí, na Zona da Mata mineira, o mostra em "Rei vagabundo", parceria com Roberto Martins, gravada por Carlos Galhardo em 1935: "lá em Mangueira eu tenho um castelo / o mais belo que há neste mundo / tem uma deusa que é minha rainha / em Mangueira, sou um rei vagabundo". Ataulfo, a propósito, foi um dos compositores "pintores" do samba, usando, no lugar da paleta, do pincel e das tintas, os acordes nostálgicos do violão que caracterizam suas composiç̃es e que, muitas vezes, são usados para definir sua mineiridade. Quem não vagueia mentalmente e devaneia, em sincera admiração, como se estivesse frente a um valioso quadro em exposição, quando ouve "Meus tempos de criança"?

O presente texto pretende restringir-se a um local que, se, por um lado, deu corpo e sustento a uma grande parcela do mundo do samba, como meio físico, por outro, eternizou-se na metáfora do lugar "pertinho do céu", próximo do poder divino: o morro. Como diz "Ave Maria no morro", de Herivelto Martins, gravada pelo Trio de ouro, em 1942, uma das canções pioneiras a metaforizar o morro como reino encantado e sede da fantasia, o barracão de zinco, lá no morro, sem telhado e sem pintura, se transforma em bangalô, ou, pelas palavras de Ataulfo, no castelo "que há de mais belo neste mundo". Na letra de "Chão de estrelas", parceria com Sílvio Caldas, gravada por este em 1937, Orestes Barbosa, depois de descrever, com singular expressividade, 
6. OLIVEIRA; MARCIER. A palavra é: favela, p. 64 .

7. SIQUEIRA, Magno Bissoli. Samba e identidade nacional: das origens à Era Vargas, p. 138 a paisagem do morro e cenas do barracão, "pinta" um chão salpicado de estrelas pela luz da lua que fura o zinco carcomido do barraco. As canções citadas adentram as profundezas da paisagem por meio de profunda idealização: no morro não se há que procurar pela felicidade que um arranha-céu oferece, ou por um bangalô. O morro é mais alto que tudo isso e sua metafórica altura, que faz o chão encontrar-se com estrelas, transmuda a tristeza em êxtase. Por isso, em "Ave Maria no morro", se diz que "quem mora lá no morro / já vive pertinho do céu".

O universo das canções que citam, enaltecem ou descrevem a vida no morro é vasto. Jane S. Oliveira e Maria H. Marcier relacionaram 163 delas, que evidenciam conteúdo relevante para análise das condições socio-históricas dessas localidades ${ }^{6}$. Por isso, as letras das canções visitadas neste trabalho, se restringem a apenas algumas que evocam paisagens típicas, com formulações simbólicas que trazem à mente o brilho e cores daquele mundo que, embora sofrido e "acinzentado" pela pobreza7, é realçado pela criação artística. Nela, a crueza da carestia da vida física, por exemplo, é mostrada como paródia da paisagem encantadora do mundo ideal. Por isso, perde nitidez e definição no confronto com o arroubo estético: a favela física, corpo desgastado e pobre, está condenado, ou abençoado, a carregar a alma da beleza da criação divina. A expressão cancionista das letras de samba cria obras virtuosas quando acessa o poder do vislumbre e da visualização pictóricas, que, aqui, metaforicamente, são equiparadas a quadros da pintura artística, emoldurados por melodias de reconhecida beleza. Retomando "Ave Maria no morro", vê-se que o artista, "compositor-pintor", completa habilmente a paisagem encantada: "tem alvorada / tem passarada / alvorecer / sinfonia de pardais / anunciando o anoitecer / E o morro inteiro / no fim do dia / reza uma prece / Ave Maria”. É uma paisagem comovente, tal como na apreciação de um quadro, pela exibição do mundo idealizado, no sonho do morro perfeito, bonito e utópico. O compositor apresenta o morro ideal, digno de protagonizar contos da fantasia, desde o "era uma vez" até o "viveram felizes para sempre”. E, note-se que não se trata, nesse aspecto, de se ter por reconhecida a estética "da feiura". Não é o feio, pela arte, que se expõe, mas a beleza visitada pela alma e pelos olhos do artista que, atormentado pelo feio cotidiano, extrai dele uma visão do belo, ainda que sofrendo, como bem cabe às expressões artísticas.

Observe-se, porém, que outras canções focam paisagen da feiura que existe na pobreza, na carência, na injustiça, esse farto material sobre o qual se construiu a vida dos morros. O samba, como arma de resistência cultural dos negros, que se viram confinados a guetos de miséria no período pós-abolicionista do Rio de Janeiro, então capital federal, e que 
8. SIQUEIRA, Magno Bissoli. Samba identidade nacional: das

origens à Era Vargas, p. 139

$$
\begin{aligned}
& \text { 9. Nasil, p. } 20 . \\
& \text {. }
\end{aligned}
$$

10. NAVES. Canção popular no Brasil, p. 25.

11. NAVES. Canção popular no Brasil, p. 23. foram compulsoriamente empurrados para as encostas dos morros ${ }^{8}$, sempre teve linguagem ferina de denúncia social, ainda quando transborda lirismo ou cria paisagens utópicas de beleza singular. Santuza Cambraia Naves ${ }^{9}$ vê na canção popular do país, "sobretudo a partir da bossa nova" (marco quase sempre relacionado à resistência ao regime militar de exceção política), um componente marcante que é um "veículo por excelência do debate intelectual, operando duplamente com o texto e com o contexto", transformando-se em canção crítica. No entanto, esse debate já acontecia, desde as origens do samba, voz de constante enfrentamento.

Acrescenta a pesquisadora que, no plano textual, "pode-se afirmar que a forma canção atingiu a sua plenitude no Brasil com a bossa nova" ${ }^{10}$, e reconhece que "coube aos compositores populares a tarefa de articular a arte com a vida"11. No que pese o autor deste ensaio concordar com a afirmativa de que os anos iniciais da bossa nova e a instauração do regime militar, principalmente no que se refere à motivação política, foram a argamassa para solidificar e avolumar a crítica cancionista, como instrumento prático de denúncia e contestação, enriquecendo-se, ainda, com a adesão de renomados poetas e escritores, resguarda e ressalta o entendimento no sentido de que a canção crítica e a articulação entre vida e arte, nasceram e amadureceram no samba, com e a partir da obra de Noel Rosa, nos anos 1930 e seguintes, dentro de um contexto social acentuadamente mais ferino que o dos anos de início da bossa nova. Ao "poeta da Vila” e "filósofo do samba", coube criticá-lo, usando como veículo a arte da canção popular em tom, muitas vezes, irônico e dúbio. Soube dosar eficientemente a amálgama que, se por um lado possibilitou a união de significativa poética com técnica composicional ${ }^{12}$, por outro, uniu expressão artística à denúncia social.

É o que, também em tempos mais recentes, se viu pelas frestas textuais, em não ditos, metáforas ou apagamentos, das "canções-pinturas" constituídas por alguns sambas do morro. Ao morador das favelas, penalizado pelo cotidiano, não raro oprimido e reprimido, muitas vezes materializando cruel metáfora de proximidade com o inferno da desdita, dá-se a compensação psicológica e simbólica de "viver pertinho do céu”, no mais belo castelo, sobre estrelas salpicadas no chão, no paraíso idealizado e que, seguramente, arroubos poéticos à parte, nunca será alcançado, mas que evoca a glória utópica do "dia seguinte" concretizada, assim na terra, como no céu. Esse paradoxo é bem retratado por Pedro Caetano e Luiz Reis na canção "Ventania no morro". O eu-lírico, preocupado, após reconhecer "tenho um amigo no morro / e quando há tempestade / eu fico aqui na cidade / morrendo de aflição / de ver aquele coitado / que vive lá pendurado / num troço desconjuntado / que chamam de barracão", se acalma, pois confia que "tem alguém segurando / e ele sabe quem é / por isso, muito tranquilo / e certo da
12. PINTO, Mayra. Noel Rosa: $o$ humor na canção, p. 23.
EM TESE
BELO HORIZONTE
v. 21
N. 3
SET.-DEZ. 2015
ROMANELLI. Alvorada lá no morro, que beleza! Hermínio, a paisagem [...] P. 104-118 
13. CAETANO. 54 anos de música popular brasileira, p. 49. proteção / ele diz ao barracão: / não precisa se afligir, / o céu fica ali pertinho / e Deus, nosso bom vizinho / não vai nos deixar cair" ${ }^{13}$

No entanto, quando se inverte a visão e, ao contrário de enaltecer o belo que transcende o feio, se coloca frente-a-frente com a feiura da realidade, a canção-paisagem se despe da aura sonhadora para realçar dramaticamente a feiura a amargura que a constrói, e transforma-se em instrumento ferino de denúncia social, econômica ou política. Aí, deriva para a estética do feio e, fria e secamente, acusa: "feio não é bonito". Na canção que leva esse título, de autoria de Carlos Lyra e Gianfrancesco Guarnieri, gravada em 1963 por Jair Rodrigues, o eu-poético sambista denuncia: "Feio, não é bonito / O morro existe / mas pede pra se acabar / canta, mas canta triste / porque tristeza / e só o que se tem pra contar".

É uma imagem expressiva e esteticamente valiosa, apesar de chocante e incômoda. Não se percebe, no exemplo, traços de utopia. Há um piso duro de realidade e um caminho que aponta, ao contrário, para um provável futuro distópico e ameaçador, quando pede para se acabar. Afinal, apesar de o morro ser "cheio de glória" por produzir e apresentar desfiles carnavalescos que alegorizam e enaltecem as riquezas do país, por meio de "escolas que falam no samba", a despeito de continuar cantando, canta de tristeza, porque "tristeza é só o que se tem pra contar". Mesmo sendo valente e nunca se deixando quebrar, o morro pede uma outra história, uma história de igualdade, de justiça social e econômica (utopia invocada no não-dito)

Percebe-se, sem muito esforço, que a grande arma de resistência do morro, na desigualdade da luta, é o samba, ${ }^{14}$, com seu ritmo sincopado ${ }^{15}$ sua voz constituinte, como bem explicita a canção "Não deixe o samba morrer", de Édson e Aluísio, gravada em 1975 por Alcione: "não deixe o samba morrer / não deixe o samba acabar / o morro foi feito de samba / de samba pra gente sambar". É o mesmo sentimento que exsuda de "Barracão", composição de Luiz Antônio e Oldemar Magalhães, gravado por Heleninha Costa em 1952: "Ai, barracão / pendurado no morro / e pedindo socorro / à cidade a seus pés". E, ainda: "Tua voz eu escuto / não te esqueço um minuto / porque sei / que tu és / barracão de zinco / tradição do meu país / barracão de zinco / pobretão infeliz...".

O barracão, um dos símbolos da tradição nacional, é presença forte na imaginação identitária do país ${ }^{16}$, por relacionar-se aos morros e, consequentemente, ao samba e, portanto, se faz presente na intelecção não só das escolas de samba como, também, da própria definição da identidade do povo brasileiro, gestada e constituída, acentuadamente, no mundo miserável do morro. A paisagem, no entanto, é sombria, cinzenta, sem brilho, é o "pobretão" símbolo da
14. Outra grande arma, e há até quem diga que é a maior de todas, é o carnaval. No entanto, nunca se pode esquecer que $o$ carnaval só pode ser assumido pela tradição negra depois da invenção do "samba de sambar do Estácio". Antes, era requinte da diversão de brancos, nos cordões, mestiçagem cerimonial nos ranchos, ou brincadeira agressiva e violenta nos entrudos, sempre tendo componente de forte discriminação racial em qualquer um deles.

15. SODRÉ, Muniz. Samba, o dono do corpo, p. 33.

16. LOPES, Nei. Bantos, malês identidade negra, p. 203. 
vida do morro, e, em grande parte, da nação, que se exaure, "pendurado", buscando ajuda na cidade que, apesar de tudo, está inerte "a seus pés", recusando-lhe olhar e visão. Há uma individualização metafórica de um problema coletivo: o barracão representa não só os barracões de todos os guetos de pobreza, mas, também, todos os demais problemas que fazem o morro padecer; o barracão, na canção, ganha vida e alma e se converte no "tu" da letra, o outro, aquele a quem se fala e que, transversalmente, recebe, como ouvinte e autoridade, as denúncias da crueza da realidade perversa para reverberá-lo pelo universo da canção e da cultura populares. Ao estabelecer diálogo com tal símbolo de tradição, mas, contraditoriamente, também de carência, o compositor aguilhoa transversalmente a cidade que, deitada a seus pés, se nega a elevar sua vista e descortinar efetivamente a paisagem do morro, entristecido pelas carências e pela injustiça.

Na crueza da realidade, o barracão é a denúncia da pobreza, mas, apesar de tudo, o sambista do morro se acalenta em dois símbolos básicos: o violão e o barracão e, para se constituir, os incorpora. Muitas vezes, quando se confronta com uma potencial ou sonhada mudança de vida, opta pela permanência ou retorno ao barracão, com todas as consequências que essa decisão possa lhe trazer. Como canta Floriano Belham em "Saudades do meu barracão", de Ataulfo Alves, gravada em 1935, no barracão, "toda riqueza que havia era um violão / e uma morena faceira / que me desprezou / só me deixando tristeza, a alegria levou". Apesar da pobreza e da tristeza "hoje choro com saudade do meu barracão". Ela "mora num arranha-céu" e ele só canta ao léu, unindo sua tristeza à tristeza de seus dois suportes tradicionais: "pobre do meu violão / já não tem mais alegria / triste do meu barracão / que é só nostalgia”. Ou, a resistência, tendo o morro e o "lugar pertinho do céu" como suportes. É o que se vê da canção "Opinião", de Zé Keti e gravada por Nara Leão em 1964: "Podem me prender / podem me bater / podem, até, deixar-me sem comer / que eu não mudo de opinião / daqui do morro / eu não saio, não / se não tem água / eu furo um poço / se não tem carne / eu compro um osso / e ponho na sopa / e deixa andar // Fale de mim quem quiser falar / aqui eu não pago aluguel / se eu morrer amanhã, seu doutor / estou pertinho do céu".

O morro convalidou-se como metafórico berço do samba e do carnaval. Existem, até hoje, discussões acaloradas, pesquisas e estudos aprofundados sobre as origens do gênero, música popular tipicamente brasileira, partícipe da formação da identidade nacional ${ }^{17}$. A maioria, em forte coro, confirma que o gênero samba, música brasileira, é o "autêntico" samba urbano carioca, que teria nascido em novembro de 1916, quando o músico Donga (Ernesto dos Santos), que não era morador dos morros, mas da Cidade Nova, depositou junto à Biblioteca Nacional a partitura de "Pelo telefone", denominando-o "samba carnavalesco". No entanto, a
17. SANDRONI, Carlos. Feitiço decente: transformações do samba no Rio de Janeiro (1917 1933), p. 133. 
18. MOURA. Tia Ciata e a pequena África no Rio de Janeiro, p. 93. "Pequena Africa no Rio de Janeiro e uma feliz identificação à região próxima dos Prazeres à regiá proxima ao centro da Nova, Gamboa, Mangue, Cais do porto pra das maiores conou a ser negras no mundo, fora da África.

19. FRANCESCHI. Samba de sambar do Estácio, p. 109. identificação morro e samba é permanente e definitiva no imaginário musical e composicional do país, independentemente da verdadeira origem ou domicílio do sambista ou compositor.

Isso faz bastante sentido quando se vê que, depois de dez anos, transitando prioritariamente a "Pequena África no Rio de Janeiro"18, em 1927, o samba passa por outra mudança e firma definitivamente o ritmo do gênero hoje reconhecido como a música do Brasil. Isso aconteceu pelas mãos (e pés) de um grupo de sambistas moradores do Bairro Estácio de Sá, que, tomando a cadência característica dos ritmos tradicionais negros, praticada nas rodas de samba e batucadas do morro, redefiniram o modo de tocar o samba urbanizado e comercializável e firmaram essa nova forma rítmica como gênero definitivo.

Como as raízes do ritmo definitivo se lançavam ao morro, para muitos pesquisadores e estudiosos e para muitos efeitos, o verdadeiro samba urbano carioca é o samba do Estácio, gestado pelo sêmen do morro ${ }^{19}$. Este é o samba que permitiu a complexidade poética da elaboração de letras preocupadas com as minúcias do cotidiano, e que, a partir das mãos e da "bossa" de Noel Rosa, pode se converter em cronista da vida sofrida dos morros e cantar "pinturas" de algumas expressivas paisagens de mundos idealizados e encantados, ou denunciadoras. Também, graças a essa nova formatação rítmica foi possível o nascimento das escolas de samba, viabilizando espetaculares apresentações na cidade que, deitada aos pés do morro, olha o espetáculo do carnaval, mas não socorre o morro ou os sambistas, que permanecem lá no alto, nos bastidores da explosão de alegria e beleza.

Não é sem razão que o samba, mensageiro da alegria carnavalesca, se converteu n' “A voz do morro”, como se vê na composição de Zé Kéti através da canção que leva esse nome, gravada por Jorge Goulart em 1955: "Eu sou o samba / A voz do morro sou eu mesmo sim senhor / Quero mostrar ao mundo que tenho valor / Eu sou o rei do terreiro / Eu sou o samba / Sou natural daqui do Rio de Janeiro / sou eu quem levo a alegria / para milhões de corações brasileiros / Salve o samba, queremos samba / Quem está pedindo é a voz do povo de um país / Salve o samba, queremos samba / Essa melodia de um Brasil feliz”.

No entanto, não se pode esquecer que, de qualquer forma, carrega forte mensagem de exaltação ao Brasil, uma maneira de compor incentivada (na prática, imposta) pelo governo de Getúlio Vargas entre os sambistas, principalmente os dos morros. A "domesticação" do morro pela elite "civilizada" e branca era necessidade governativa do caos social em que se transformara o Rio de Janeiro, além de os governos populistas municipal, de Pedro Ernesto, e federal, de Getúlio, terem percebido a necessidade política de incorporar os habitantes
EM TESE
BELO HORIZONTE
v. 21
N. 3
SET.-DEZ. 2015
ROMANELLI. Alvorada lá no morro, que beleza! Hermínio, a paisagem [...] P. 104-118 
20. PAVAN. Timoneiro: perfil biográfico de Hermínio Bello de
Carvalho, p. 43-44. do morro à cidadania brasileira, contribuindo para constituir a identidade nacional.

Uma das primeiras "convenções" desse acordo foi a reforma das letras dos sambas, que deveriam veicular mensagens contrárias à malandragem e que exaltassem as qualidades nacionais; outra, foram os enredos carnavalescos que, $\mathrm{d}$ mesma forma, deveriam louvar apenas as boas coisas do país. Desde "Aquarela do Brasil”, de Ary Barroso, gravada em 1939 por Francisco Alves, essa forma de composição pertence ao subgênero "samba-exaltação", que tem, como objetivo, o enaltecimento das belezas do país e a valorização do trabalho útil, honesto e dedicado do operariado. Essa aderência a um estilo cancioneiro panfletário, no entanto, não prejudica de nenhuma forma, a qualidade musical ou poética da canção, nem seu apelo social, já que o samba, rei do terreiro, natural do Rio de Janeiro, que leva a alegria para milhões de corações brasileiros, tem que pedir permissão para mostrar ao mundo inteiro o seu valor.

O objetivo deste trabalho, porém, é o de apresentar algumas letras de canções de autoria de Hermínio Bello de Carvalho, descritivas de paisagens dos morros e sugestivas de formulações pictóricas. Já aos 19 anos, o letrista, escrevia poemas e crônicas e tinha se iniciado no mundo radiofônico e jornalístico ${ }^{20}$. Na canção, Hermínio não se amarrou ao gênero samba, nem ao saudosismo da canção tradicional dos morros. No entanto, com poética aclamada no meio musical, "pintou", pelo samba, alguns dos mais importantes quadros das paisagens dos morros. Mangueirense convicto, sempre se refere ao Morro da Mangueira, forte musa inspiradora.

Jairo Severiano ${ }^{21}$ aponta o letrista como sendo um dos expoentes da "geração que fixou a moderna canção brasileira" dentre um "numeroso grupo de artistas consagrados fora dos festivais, embora deles tenham também participado". Hermínio é um artista multitarefas, conhecido em todas as áreas do mundo da canção popular: da poesia às colunas de jornais e revistas; do violão, às letras de música; do rádio às promoções culturais (foi um dos promotores culturais do fenômeno "Zicartola”, dentre outros de relevância similar). "Parceiro e amigo de Pixinguinha, Cartola, Chico Buarque e outros ases", lembra Jairo Severiano 22 "o poeta, compositor e produtor cultural [...] possui uma vasta folha de serviços prestados à cultura nacional que inclui, além de uma memorável série de projetos bem-sucedidos, a descoberta" de grandes artistas de nossa canção, como, por exemplo, dentre outros, Clementina de Jesus e Paulinho da Viola.

Serão vistas aqui cinco canções, em que cuidou da letra e, portanto, da carga imagética e pictórica da mensagem, cada uma delas descrevendo paisagens peculiares. Pela ordem cronológica, são elas: "Cicatriz", composição feita em parceria com Zé Kéti, gravada em 1965 por Nara Leão; "Alvorada”,
21. SEVERIANO. Uma história da música popular brasileira p. 379-380.

22. SEVERIANO. Uma história da música popular brasileira, p. 413.
EM TESE
BELO HORIZONTE
v. 21
N. 3
SET.-DEz. 2015
ROMANELLI. Alvorada lá no morro, que beleza! Hermínio, a paisagem [...] $\quad$ P. 104-118 
23. PAVAN. Timoneiro: perfil biográfico de Hermínio Bello de Carvalho, p. 42, 46, 57. parceria com Cartola e Carlos Cachaça, gravada em 1968 por Odete Amaral; "Sei lá, Mangueira", parceria com Paulinho da Viola, gravada também em 1968 e também por Odete Amaral (ambas no mesmo álbum, "Fala, Mangueira!"); "A Mangueira é lá no céu”, parceria com Sebastião Tapajós, gravada em 1970 por Clementina de Jesus, e "Chão de esmeraldas", parceria com Chico Buarque e gravada por este em 1997.

Para que se faça um passeio por essas canções, à semelhança de uma visita à exposição de pinturas, e, inspirando-se em Mussorgsky, um trânsito coerente e refletido entre os quadros dessa peculiar exposição, a ordem cronológica será deixada de lado e observada a seguinte sequência: "Cicatriz", "A Mangueira é lá no céu", "Alvorada", "Chão de esmeraldas" e, finalmente, "Sei lá, Mangueira”. Este, o passeio que, ressalvada a preferência de cada apreciador, se apresenta, pela visão e pela pena do escritor, como de mais adequado impacto imaginativo dentro da estética das paisagens expostas. Antes, uma observação. O lirismo acentuado do letrista é filho de sua veia poética. Muito antes de trilhar o caminho de cancionista, já violonista, publicara livros de poemas, se aconselhara com Carlos Drummond de Andrade e confrontara Manuel Bandeira ${ }^{23}$. Não bastasse sua paixão anterior pelo violão, seus contatos radiofônicos, suas amizades, a veia musical era francamente notada em sua poesia, a exemplo do comentário crítico de Álvaro Moreyra, sobre o livro de poemas “Ária \& percussão”, lançado em 1962: “O livro tem nome de música e é música. Chega de repente, entra pelos olhos, acorda os ouvidos, para, continua, ressoando, pondo reflexos na solidão que criou" ${ }^{24}$. E conclui, observando agora a veia pictórica da poética: "Clarão tornado sombra. Sombra tornada clarão. Silêncio dissolvido em alma”.

Em “Cicatriz", a primeira canção da lista, e da exposição, o letrista contesta a pobreza das favelas e reclama "pobre nunca teve gosto / a tristeza é a sua cicatriz”. Ainda, pontua o aumento da miséria: "pobre não é um / pobre é mais de dois / muito mais de três". Denuncia: "reparem bem que só de vez em quando / pobre é feliz / ai, quanto desgosto! / Assim a vida vale a pena? Não!" No entanto, aponta para a riqueza que contribui para valorizar a vida ruim do pobre do morro e para que ela seja suportada e superada: a paisagem. A paisagem é o elemento que ameniza a dor da carência. Se não se tem quase nada de bens materiais ou dinheiro, tem-se muito no maravilhamento da paisagem: "Deus, dando a paisagem / metade do céu já é meu / [...] / Deus, dando a paisagem / o resto é só ter coragem". É o alento da espera na intervenção de um ente superior que pode - e, utopicamente, vai - amenizar o tormento, mas que se mostra, no agora, presente apenas na grandiosidade da paisagem, da paisagem que só quem vive no morro é que conhece, pois é quem "vive pertinho do céu". Do mesmo céu que enfeita a cúpula celeste do morro da Mangueira e que faz o artista figurar o quadro seguinte, a canção "A Mangueira é lá no céu”.
EM TESE
BELO HORIZONTE
v. 21
N. 3
SET.-DEZ. 2015
ROMANELLI. Alvorada lá no morro, que beleza! Hermínio, a paisagem [...] P. 104-118

24. PAVAN. Timoneiro: perfil biográfico de Hermínio Bello de Carvalho, p. 63 
Esta é uma canção que homenageia grandes mestres cancionistas da Mangueira, tais como Cartola, Geraldo Pereira, Zé com Fome, Carlos Cachaça e Gradim, dentre os "demais compositores / daquela escola tão genial”. E ao visitar o morro e se aproximar metaforicamente do céu estrelado, o letrista procura alcançar a memória dos grandes artistas: "Vou visitar lá em Mangueira / o divino mestre Cartola / e os demais compositores / daquela escola tão genial // Vou pedir que me levem lá pro céu / que cada dia chega mais perto do morro / e onde já viram Deus compondo / um samba para escola desfilar".

Como se vê, a percepção e a apreensão da paisagem pelo artista traz o céu cada vez mais para perto do pobre morador do morro. É disso que o morro carece; é isso que o morro merece: o céu e as bênçãos do Divino, porque o resto parece impossível de se atingir. O compositor, em uma ânsia lírica de esperança, afirma e crê que o céu "cada dia chega mais perto do morro", até que um dia, enfim, o bafeje com suas bênçãos. Não é, evidentemente, o céu das estrelas físicas, o espaço cósmico pontilhado das luzes das estrelas, que o artista pincela mas o céu de que carece o morro, o céu da felicidade e do amparo social, o céu do reconhecimento e do acolhimento.

A visão do céu, tido como uma das paisagens mais marcantes do morro, evoca a aproximação utópica do real feliz, pela intervenção do deus que mora nas alturas e que estenderá as mãos ao pobre morador, a exemplo de "A criação de Adão", de Michelangelo Buonarroti, famoso afresco do teto da Capela Sistina, no Palácio Apostólico, no Vaticano. A vez do morro é o que se espera para logo, e com tanta expressividade que o delírio poético de ver Deus compondo um samba para a escola desfilar, faz todo sentido de materialização do samba-enredo perfeito, divinamente inspirado. É o sagrado momento em que as mãos de Deus e do sambista se tocam, ainda que apenas pelas pontas dos dedos, mas de dedos que tangem as cordas do violão. Ampliando ao máximo a idealização da música perfeita, o eu-lírico pretende pedir aos grandes talentos do morro que o levem para o céu, claro que por meio de uma canção divinamente inspirada, que eleva o nome dos artistas às esferas celestiais, às altas possibilidades sagradas nos sonhos de homenageá-los: "Juro, não sei o que faria / se eu fosse dono lá do céu / em cada estrela escreveria / o nome de um compositor". Cada compositor, diz a canção, merece ser inscrito em um trono celestial para distribuir seu brilho eternamente, como estrela da arte que é, nos céus metafóricos do universo do samba.

A união de Hermínio com outros dois expoentes do cancioneiro pátrio, Cartola e Carlos Cachaça, oferece à arte nacional a canção "Alvorada". Com acentuada dose de lirismo, a canção retrata o morro no acordar ainda sonolento, na felicidade sonambúlica do quase encontro com a possibilidade 
de se ver consumada a utopia do novo dia que nasce. É a antevisão, só possível nos entremeios do mundo real com o dos sonhos, do "novo dia", que bem poderia ser hoje, finalmente instaurado. Alheia ao cotidiano da realidade, a beleza se constitui e se faz presente naquele instante mágico, construindo a paisagem do morro na aurora. Afinal, "Alvorada lá no morro / que beleza / ninguém chora / não há tristeza / ninguém sente dissabor / O sol colorindo é tão lindo / é tão lindo / e a natureza sorrindo / tingindo, tingindo"

O passeio pelos "quadros" desta exposição leva o observador aos caminhos pavimentados de pedras preciosas, mais precisamente, de esmeraldas, que dão indescritível brilho ao chão do morro da Mangueira, na canção "Chão de esmeraldas", evidente diálogo com "Chão de estrelas". E, por esse caminho iluminado, o compositor faz com que o observador passeie e seja atraído ao cerne da paisagem encantada, ao reino da fantasia, à morada do sublime e do belo. A canção atua como um portal que atrai hipnoticamente a um mundo do esteticamente perfeito, materializado pelo samba: o morro da Mangueira, que, no desfile carnavalesco, atinge o ideal da beleza pura: "Me sinto pisando / um chão de esmeraldas / quando levo meu coração / à Mangueira / Sob uma chuva de rosas / meu sangue jorra das veias / e tinge um tapete / pra ela sambar / é a realeza dos bambas / que quer se mostrar / soberba, garbosa / Minha escola é um cata-vento a girar / É verde, é rosa / Oh, abre alas para a Mangueira passar”. É ali, naquele instante apoteótico, que, do eu-lírico, jorra sangue de pura poesia, metáfora que dialoga com a passagem cristã da paixão do Cristo oferecendo vinho, simbolizando sangue, para tingir o tapete por onde a escola desfila e samba. Instaura-se a realeza da arte do samba manifestado em desfile, pelas mãos, pés e alma dos bambas da escola que apresentam o garbo e a soberba da expressão carnavalesca que, inexprimível, se materializa em um singelo cata-vento, verde e rosa, a girar.

O arroubo de paixão do letrista pelo morro, esse morro que fala por canções e pela escola de samba, encontra a expressão mais comemorada em “Sei lá, Mangueira”. A canção entrou para o folclore musical do samba como foco de constrangimento para um de seus compositores, que trabalhou a melodia, o poeta-pensador do samba, mas portelense de coração, Paulinho da Viola. A letra já fora escrita e estava engavetada pelo amigo e parceiro Hermínio e este, em um dos encontros com o portelense, pediu que a musicasse. Paulinho o fez, mas a intensa expressividade da canção, na adequada combinação de letra e música, que a transformou em sucesso imediato, acabou por elevá-la a um dos consagrados hinos do morro da Mangueira, causando um certo mal-estar entre os portelenses.

Para se redimir, Paulinho compôs "Foi um rio que passou em minha vida”, gravada pelo autor em 1969, enaltecendo, 
25. MÁXIMO. Paulinho da Viola: sambista e chorão, p. 85-87. de maneira não menos lírica, a Escola de Samba Portela, do bairro Oswaldo $\mathrm{Cruz}^{25}$. O eu-poético, nesta canção, começa justificando-se pela infidelidade e pelo "desvio", em contrito mea culpa, por ter pecado contra a sacralidade dos laços que o une à escola, mas, esclarece, o fez apenas porque tem a mania de amar e o amor é universal: "se um dia meu coração for consultado / para saber se andou errado / será difícil negar. / Meu coração tem mania de amor". Conclui a canção enaltecendo as cores e a beleza da Escola, e reafirmando solenemente o fiel amor de portelense: "não posso definir / aquele azul / não era do céu / não era do mar. / Foi um rio que passou em minha vida / e meu coração se deixou levar". Perdão concedido de imediato, absoluto e eterno.

Retomando o passeio pelos "quadros" da exposição, estaca-se frente à nova e exuberante paisagem do morro da Mangueira: "Vista assim do alto / Mais parece um céu no chão / Sei lá / em Mangueira a poesia fez um mar, se alastrou / e a beleza do lugar, pra se entender / tem que se achar / Que a vida não é só isso que se vê / é um pouco mais / que os olhos não conseguem perceber / e as mãos não ousam tocar / e os pés recusam pisar / Sei lá não sei... / Sei lá não sei... // Não sei se toda beleza de que lhes falo / sai tão somente do meu coração / Em Mangueira a poesia / num sobe e desce constante / anda descalça ensinando / um modo novo da gente viver / de sonhar, de pensar e sofrer / Sei lá não sei, sei lá não sei não / A Mangueira é tão grande / que nem cabe explicação".
O eu-lírico observa o morro da Mangueira, de forma panorâmica, por um ângulo espacialmente elevado, bastante acima do nível do solo, podendo visualizar todo o conjunto de habitações. Demonstra-se embevecido com a visão descortinada diante de si, uma das expressivas paisagens da canção brasileira. Do alto, observa como se já no céu estivesse. Tanto o céu se achegou ao morro, que há uma transfiguração no encontro. Céus e morro se alcançam e a partir da visão divinamente inspirada, é possível tentar compreender a grandeza do encontro.

Para o observador, as luzes das residências, acessas, passaram a repetir o céu no chão, como se o espelhasse. O céu, que a cada dia mais se aproximava do morro, acabou por derramar-se em um mar de poesia que se alastrou pelas encostas. No entanto, tal encantamento é privilégio do observador que acorda para a inspiração e vê, não um espaço pontilhado por luzes, mas, ao contrário, a vida que o constitui e anima. Percebe que a vida não é só o que se vê, é mais que isso, sagrada para os olhos que não ousam tocar, e para os pés, que recusam pisar. É a transgressão do natural, a que se é habituado, pela superação do real; a força da beleza que emana da compreensão artística transcende os sentidos físicos. Por trás da visão física, do contato material de mãos que tocam e pés que pisam, há sopro da essência original da vida, dando expressão ao mundo criado pela arte. 
26. ROMANELLI. Roda de samba, roda da vida: filosofia de em Noel, Paulinho e Chico, p. 167.
Quem se privilegia do olhar da arte verá mais do que é possível à simples capacidade de admirar e refletir, e alcançará a possibilidade de imergir no substrato da criação, no "ser-em-si" que há por trás do mundo das aparências. A capacidade de enxergar as profundezas e transcender o aparente, recriando o mundo, é o que instaura a arte e valida o artista. $\mathrm{Na}$ canção, o sujeito poético se arrebata ao "ver" o mar de luzes espalhado pela encosta, e ao sentir a alma da paisagem. Nas potencialidades de um simples cotidiano, cáustico para os moradores que transitam pela vida pobre do morro, resgatou a força e a expressão do movimento perpétuo da poesia. E dali extraiu a essência artística do "sobe e desce" constante e banal da existência. Nesse movimento, de pessoas que transitam na simplicidade do existir, o eu-lírico percebe a sabedoria de uma ancestralidade perdida nos séculos e nas distâncias da tradição, "um conhecimento tradicional que ensina a sonhar, a pensar e a sofrer; a alma do mundo e da filosofia do Samba. O sonho produz arte; o pensamento, reflexões, e o sofrer, a sabedoria de vida"26.

É um universo de plena harmonização, de poética irresistível e de uma beleza "tão grande / que não cabe explicação". Sei lá, não sei.

\section{REFERÊNCIAS}

CAETANO, Pedro. $\mathbf{5 4}$ anos de Música Popular Brasileira: o que fiz, o que vi. 2. ed. ilustrada e aumentada. Rio de Janeiro: Pallas, 1988

FAUSTINO, Mário. Que é poesia? In FAUSTINO, Mário. Poesiaexperiência. São Paulo: Perspectiva, 1977.

FRANCESCHI, Humberto M. Samba de sambar do Estácio: de 1928 a 1931. 1. reimp. São Paulo: Instituto Moreira Salles, 2014

LOPES, Nei. Bantos, malês e identidade negra. 3 ed. Belo Horizonte: Autêntica, 2011

MÁXIMO, João. Paulinho da Viola: Sambista e chorão. Rio de Janeiro: Relume Dumará, 2002. (Col. Perfis do Rio).

MERLEAU-PONTY, Maurice. A prosa do mundo. Trad. Paulo Neves. São Paulo: Cosac Naify, 2012

\section{MOURA, Roberto. Tia Ciata e a pequena África no Rio de} Janeiro. 2. ed. Rio de Janeiro: Secretaria Municipal de Cultura 1995

NAVES, Santuza Cambraia. Canção popular no Brasil. Rio de Janeiro: Civilização Brasileira, 2010.

OLIVEIRA, Jane Souto de; MARCIER, Maria Hortense. "A palavra é: favela". In ZALUAR, Alba; ALVITO, Marcos (org.). Um século de Favela. 5. ed. Rio de Janeiro: Ed. FGV, 2006.

PAVAN, Alexandre. Timoneiro: Perfil biográfico de Hermínio Bello de Carvalho. Rio de Janeiro: Casa da palavra, 2006.
EM TESE
BELO HORIZONTE
v. 21
N. 3
SET.-DEZ. 2015
ROMANELLI. Alvorada lá no morro, que beleza! Hermínio, a paisagem [...] P. 104-118 
PINTO, Mayra. Noel Rosa: o humor na canção. São Paulo: Ateliê:

Fapesp, 2012.

ROMANELLI, Francisco A. Roda de samba, roda da vida

filosofia de botequim em Noel, Paulinho e Chico. Varginha: Ed.

do autor, 2015.

SANDRONI, Carlos. Feitiço decente: transformações do samba no Rio de Janeiro (1917-1933). 2. ed. ampl. Rio de Janeiro: Zahar, 2012

SCHØLLHAMMER, Karl Erik. Além do visível: o olhar da

Literatura. Rio de Janeiro: 7 Letras, 2007.

SEVERIANO, Jairo. Uma história da música popular brasileira:

das origens à modernidade. São Paulo: Ed. 34, 2008.

SIQUEIRA, Magno Bissoli. Samba e identidade nacional: das origens à Era Vargas. São Paulo: Unesp, 2012.

SODRÉ, Muniz. Samba, o dono do corpo. 2 ed., 2 reimp. Rio de Janeiro: Mauad, 2007. 